\title{
PENENTUAN KEUNTUNGAN MAKSIMUM PADA PENJUALAN OLAHAN TAPE DENGAN MENGGUNAKAN METODE LAGRANGE (Studi Kasus: UD. Sari Madu)
}

\author{
FEMy AyU Astiti $^{1}$, Ni MAde AsiH ${ }^{2}$, I NyOMAN WidANA $^{3}$ \\ ${ }^{1,2,3}$ Jurusan Matematika FMIPA Universitas Udayana, Bukit Jimbaran-Bali \\ e-mail: ${ }^{1}$ femy_novitasari@yahoo.co.id \\ 22sedhana20@gmail.com, 3nwidana@yahoo.com
}

\begin{abstract}
Optimization problems can be solved by various methods, such as Lagrange Method. This method can be used to find the solution. Using Lagrange method, the extreme value can be obtained, so that the optimal solution can be found. In this research, the maximum revenue of UD. Sari Madu is a limited by several constraints. After the objective function and constraint function being model, than maximum revenue is found. From first until fourth quarterly, the maximum revenue is found Rp. 9.701.333, Rp. 10.064.148, 9.793.272 and Rp. 9.397.730 respectively.
\end{abstract}

Keywords: Lagrange Method, Ekstrem Value, Optimization

\section{Pendahuluan}

Dalam sebuah perusahaan, hal yang ingin dicapai adalah mendapatkan keuntungan yang maksimum. Besarnya harga yang diberikan oleh supplier/perusahaan kepada pelanggan, akan memengaruhi jumlah keuntungan yang didapat. Apabila menentukan harga terlalu rendah, maka keuntungan yang diperoleh dari hasil penjualan produknya, akan rendah. Apabila menentukan harga terlalu tinggi, maka akan menurunkan minat pelanggan untuk membeli produk tersebut, yang akan mengakibatkan penurunan omzet perusahaan.

Dalam memaksimalkan keuntungan, dapat diselesaikan dengan optimasi matematika yang dilakukan dengan menggunakan program linear, program tak linear, program integer dan program dinamik (Cleland, [2]).

Teknik optimasi dapat digunakan untuk menyelesaikan permasalahan dengan fungsi berkendala maupun tak berkendala. Bentuk penyelesaian permasalahannya dapat berupa persamaan atau pertidaksamaan. Unsur terpenting pada suatu masalah optimasi adalah fungsi tujuan yang bergantung pada sejumlah peubah masukkan. Peubah-peubah ini dapat saling bergantung atau tidak, melalui satu atau lebih kendala (Bronson,[1]).

Metode Lagrange merupakan sebuah teknik yang dapat digunakan menyelesaikan masalah optimasi dengan kendala persamaaan. Inti dari metode ini

\footnotetext{
${ }^{1}$ Alumni Mahasiswa Jurusan Matematika FMIPA Universitas Udayana

${ }^{2,3}$ Staf Pengajar Jurusan Matematika FMIPA Universitas Udayana
} 
adalah mengubah titik ekstrem terkendala menjadi persoalan titik ekstrem bebas kendala. Sehingga dengan metode ini, didapat solusi untuk memperoleh keuntungan maksimum.

\section{Metode Penelitian}

Sumber data yang diperoleh dalam penelitian ini berasal dari observasi langsung dan dari data sekunder, yaitu data yang diperoleh melalui dokumendokumen yang telah tersedia di (UD. Sari Madu) yang merupakan supplier tape di Tiara Group dan Hardy's Group. Dengan periode data 1 tahun (1 April 2011 - 31 Maret 2012).

Dalam penelitian ini, variabel yang digunakan adalah jenis tape dan harga tape. Untuk variabel jenis tape yaitu tape besar $\left(x_{1}\right)$, tape kecil $\left(x_{2}\right)$, tape bakar $\left(x_{3}\right)$, jajan tape $\left(x_{4}\right)$, dan tape ketan $\left(x_{5}\right)$. Dan untuk variabel harga tape yaitu harga tape yang di produksi dan harga jual produksi di supermarket.

Tahapan analisis pada penelitian ini meliputi :

1. Memodelkan masalah optimasi dalam bentuk sistem persamaan linear.

1) Menentukan variabel keputusan

Langkah awal dalam memodelkan suatu masalah yaitu dengan menentukan variabel-variabel yang berpengaruh di dalamnya. Untuk memodelkan masalah optimasi keuntungan pengiriman tape beserta olahannya ke dalam bentuk sistem persamaan linear terdapat beberapa variabel yaitu :

$x_{1}=$ Jumlah pengiriman tape kemasan besar

$x_{2}=$ Jumlah pengiriman tape kemasan kecil

$x_{3}=$ Jumlah pengiriman jajan tape

$x_{4}=$ Jumlah pengiriman tape bakar

$x_{5}=$ Jumlah pengiriman tape ketan

2) Menentukan fungsi tujuan

Tujuan yang ingin dicapai oleh perusahaan adalah untuk memperoleh keuntungan maksimum setiap jenis tape beserta olahannya. Hal ini diperoleh dari selisih antara harga produksi dengan harga jual produksi. Fungsi tujuan yang dapat dibentuk yaitu :

Tabel 1. Tabel Bentuk Baku Fungsi Tujuan

\begin{tabular}{|l|c|c|c|c|c|}
\hline Supermarket & $\begin{array}{l}\text { Tape Besar } \\
x_{1}\end{array}$ & $\begin{array}{l}\text { Tape Kecil } \\
x_{2}\end{array}$ & $\begin{array}{l}\text { Tape Bakar } \\
x_{3}\end{array}$ & $\begin{array}{l}\text { Jajan Tape } \\
x_{4}\end{array}$ & $\begin{array}{l}\text { Tape Ketan } \\
x_{5}\end{array}$ \\
\hline \hline Harga produksi & 4400 & 2700 & 2900 & 2950 & 2700 \\
\hline Harga jual produksi & 6000 & 4000 & 3500 & 4000 & 3500 \\
\hline Keuntungan & 1600 & 1300 & 600 & 1050 & 800 \\
\hline
\end{tabular}


Sehingga dari table 1 dapat dibentuk fungsi tujuan Maks $f(x)=1600 x_{1}+1300 x_{2}+600 x_{3}+1050 x_{4}+800 x_{5}$

3) Menentukan fungsi batasan

Fungsi batasan dibentuk berdasarkan masing-masing supermarket, kemudian mencari peluang masing-masing produk terhadap total produk tersebut diproduksi dengan syarat batasan harus lebih kecil dari jumlah pengiriman pada masing-masing supermarket.

Periode waktu yang digunakan selama 1 tahun yang dipartisi menjadi 4 bagian, setiap bagian terdiri dari 3 bulan (triwulan). Bentuk baku fungsi batasannya yaitu:

Tabel 2. Tabel Bentuk Baku Pengiriman Tape dan Olahannya

\begin{tabular}{|l|c|c|c|c|c|c|}
\hline Toko Jenis & $\begin{array}{c}\text { Koef } \\
x_{1}\end{array}$ & $\begin{array}{c}\text { Koef } \\
x_{2}\end{array}$ & $\begin{array}{c}\text { Koef } \\
x_{3}\end{array}$ & $\begin{array}{c}\text { Koef } \\
x_{4}\end{array}$ & $\begin{array}{c}\text { Koef } \\
x_{5}\end{array}$ & Total \\
\hline Tiara Group & $a_{11}$ & $a_{12}$ & $a_{13}$ & $a_{14}$ & $a_{15}$ & $\Sigma y_{1}$ \\
\hline Hardy's Group & $a_{21}$ & $a_{22}$ & $a_{23}$ & $a_{24}$ & $a_{25}$ & $\Sigma y_{2}$ \\
\hline Total & $\Sigma x_{1}$ & $\Sigma x_{2}$ & $\Sigma x_{3}$ & $\Sigma x_{4}$ & $\Sigma x_{5}$ & $\Sigma x y$ \\
\hline
\end{tabular}

Sehingga fungsi batasan yang dapat dibentuk adalah

Fungsi batasan triwulan I (April, Mei, Juni)

$0,700 x_{1}+0,704 x_{2}+0,703 x_{3}+0,698 x_{4}+0,696 x_{5} \leq 4266$

$0,300 x_{1}+0,296 x_{2}+0,297 x_{3}+0,302 x_{4}+0,304 x_{5} \leq 1819$

$x_{1}, x_{2}, x_{3}, x_{4}, x_{5} \geq 0$

\section{Fungsi batasan triwulan II (Juli, Agustus, September)}

$0,631 x_{1}+0,626 x_{2}+0,641 x_{3}+0,662 x_{4}+0,526 x_{5} \leq 3968$

$0,369 x_{1}+0,374 x_{2}+0,359 x_{3}+0,338 x_{4}+0,474 x_{5} \leq 2400$

$x_{1}, x_{2}, x_{3}, x_{4}, x_{5} \geq 0$

Fungsi batasan triwulan III (Oktober, November, Desember)

$0,654 x_{1}+0,649 x_{2}+0,667 x_{3}+0,666 x_{4}+0,615 x_{5} \leq 4003$

$0,346 x_{1}+0,351 x_{2}+0,333 x_{3}+0,336 x_{4}+0,385 x_{5} \leq 2151$

$x_{1}, x_{2}, x_{3}, x_{4}, x_{5} \geq 0$

Fungsi batasan triwulan IV (Januari, Februari, Maret)

$0,617 x_{1}+0,615 x_{2}+0,624 x_{3}+0,598 x_{4}+0,533 x_{5} \leq 3624$

$0,383 x_{1}+0,385 x_{2}+0,376 x_{3}+0,402 x_{4}+0,467 x_{5} \leq 2332$

$x_{1}, x_{2}, x_{3}, x_{4}, x_{5} \geq 0$

2. Menentukan titik optimum dengan menggunakan Metode Lagrange.

Setelah kita menentukan variabel keputusan, memodelkan fungsi tujuan dan fungsi batasan maka akan dicari nilai untuk masing-masing nilai $x$, untuk masing-masing triwulan dengan bantuan software Maple. Setelah memperoleh nilai $x$, maka akan dicari nilai $\lambda$ untuk masing-masing kendala. Dengan 
mengetahui titik-titik kritis dan nilai $\lambda$, substitusi ke dalam fungsi Lagrangian (Rao,[3]) yang didefinisikan sebagai berikut

$$
L(x, \lambda)=f(x)+\sum_{j=1}^{m} \lambda_{j} g_{j}(x) \quad \text { untuk nilai } \mathrm{j}=1,2,3, \ldots, \mathrm{m}
$$

Sehingga akan diperoleh keuntungan maksimum penjualan tape beserta olahannya.

\section{Hasil dan Pembahasan}

Menentukan nilai optimum pada triwulan 1, untuk mencari masing-masing nilai $x$, digunakan software Maple untuk mempermudah perhitungan, sehingga diperoleh nilai

$x_{1}=6063.3333, x_{2}=0, x_{3}=0, x_{4}=0, x_{5}=0$. Dengan mengetahui nilai $x$, nilai $\lambda$ diperoleh dengan cara mensubstitusi fungsi kendala ke dalam persamaan :

$$
\lambda_{j} \times g_{j}(x)=0
$$

Maka akan diperoleh nilai $\lambda_{1}=0$ dan $\lambda_{2}=0$. Dengan memasukkan nilai $x_{1}, x_{2}, x_{3}, x_{4}, x_{5}$ dan $\lambda_{1}, \lambda_{2}$ yang telah diperoleh ke dalam fungsi Lagrangian maka didapat nilai $f(x)=9701333$.

Hasil tersebut menunjukan bahwa perusahan ini akan mencapai keuntungan maksimum apabila memproduksi tape kemasan besar $\left(x_{1}\right)$ sebanyak 6063 pcs. Produk lain seperti tape kemasan kecil $\left(x_{2}\right)$, jajan tape $\left(x_{3}\right)$, tape bakar $\left(x_{4}\right)$ dan tape ketan $\left(x_{5}\right)$ tidak perlu diproduksi. Karena hanya dengan memproduksi $x_{1}$, perusahaan akan mencapai keuntungan maksimum tanpa memproduksi produk yang lainnya yaitu sebesar Rp. 9.701.333

Dengan langkah yang sama seperti pada triwulan 1, maka hasil yang diperoleh untuk triwulan 2, 3 dan 4 apabila dibentuk dalam tabel maka hasilnya adalah

Tabel 3. Tabel Keuntungan Maksimum Triwulan

\begin{tabular}{|c|c|c|c|c|c|c|}
\hline Triwulan & $\boldsymbol{x}_{\boldsymbol{1}}(\mathrm{pcs})$ & $\boldsymbol{x}_{2}(\mathrm{pcs})$ & $\boldsymbol{x}_{\boldsymbol{3}}(\mathbf{p c s})$ & $\boldsymbol{x}_{4}(\mathrm{pcs})$ & $\boldsymbol{x}_{5}(\mathrm{pcs})$ & $\begin{array}{c}\text { Keuntungan } \\
(\mathbf{R p})\end{array}$ \\
\hline I & 6.063 & 0 & 0 & 0 & 0 & 9.701 .333 \\
\hline II & 6.288 & 0 & 0 & 0 & 0 & 10.064 .148 \\
\hline III & 6.120 & 0 & 0 & 0 & 0 & 9.793 .272 \\
\hline IV & 5.874 & 0 & 0 & 0 & 0 & 9.397 .730 \\
\hline
\end{tabular}

Hal ini menunjukkan bahwa perusahaan ini akan mencapai keuntungan maksimum hanya dengan memproduksi tape kemasan besar $\left(x_{1}\right)$. 


\section{Kesimpulan}

1) Fungsi tujuan dibentuk dengan cara mengalikan keuntungan dengan masing-masing produk tape sehingga diperoleh model sebagai berikut: Maks $f(x)=1600 x_{1}+1300 x_{2}+600 x_{3}+1050 x_{4}+800 x_{5}$

2) Dari triwulan I sampai IV, produk yang harus diproduksi adalah tape kemasan besar $\left(x_{1}\right)$. Jumlah produksi sebanyak 6063 pes dengan keuntungan Rp. 9.701.333, 6288 pcs dengan keuntungan Rp. 10.061.489, 6121 pcs dengan keuntungan Rp. 9.793.272, dan 5874 pcs dengan keuntungan .

\section{Daftar Pustaka}

[1] Bronson, R. 1982. Theory and Problem of Operations Research. USA: McGraw Hill Inc.

[2] Cleland, D.I. dan D.F. Kacaogln. 1980.Engineering Management. Johanesburg: McGraw Hill International Book Company

[3] Rao, S.S. 1984. “Optimization Theory and Applications (Second Edition)”. USA: Deptt of mechanical Engg.San Diego State University 